\title{
Desalination as a Negative Emissions Technology
}

\author{
P. A. Davies ${ }^{1 *}$, Q. Yuan ${ }^{1}$ and R. de Richter ${ }^{2}$ \\ ${ }^{1}$ Aston Institute of Materials Research, School of Engineering and Applied Science, Aston \\ University, Birmingham B4 7ET, UK \\ 2 Tour-Solaire.fr, 8 Impasse des Papillons, 34090 Montpellier, France. \\ * Corresponding author: p.a.davies@aston.ac.uk
}

\begin{abstract}
To limit global warming, governments and industries are engaged in reducing emissions of $\mathrm{CO}_{2}$. There is increasing evidence, however, that it may be necessary to go a step further by removing $\mathrm{CO}_{2}$ already emitted. For the purpose of Carbon Dioxide Removal (CDR), a number of Negative Emissions Technologies (NET) have been proposed. These generally make extensive usage of land, energy and water - if they are to be implemented at the large scales needed. It is therefore important to seek, investigate and compare alternative approaches to NET. Desalination plants, though normally seen as sources rather than sinks of $\mathrm{CO}_{2}$, could be modified to provide a new type of NET. In this study, we propose treating desalination reject brine by electrolysis to form $\mathrm{Mg}(\mathrm{OH})_{2}$ and thus absorb $\mathrm{CO}_{2}$ via the oceans. The energy and water penalties associated with the electrolysis are calculated as $1.8 \mathrm{GJ} / \mathrm{tCO}_{2}$ and $13.7 \mathrm{~m}^{3} / \mathrm{tCO}_{2}$ respectively, making it an interesting option in comparison with some other types of NET. However, NET-modification more than doubles the specific energy consumption of a reverse-osmosis desalination plant. It is concluded that NET-desalination has potential to contribute to CDR in arid countries (especially if solar energy is used) thus helping to meet Intended Nationally Determined Contributions (INDCs) following the COP21 summit.
\end{abstract}

Keywords: carbon dioxide removal; negative emissions technology; reverse osmosis; brine management; specific energy consumption.

\author{
Abbreviations: \\ AW - Accelerated weathering \\ BECCS - Bioenergy with Carbon Capture and Storage \\ CDR - Carbon Dioxide Removal \\ DAC - Direct Air Capture \\ GDA - Gas Diffusion Anode \\ INDC - Intended Nationally Determined Contributions \\ NET - Negative Emissions Technology \\ OL - Ocean Liming \\ $\mathrm{RO}$ - Reverse Osmosis \\ SEC - Specific Energy Consumption
}




\section{Introduction}

\subsection{The growing importance of Carbon Dioxide Removal}

At the Conference of the Parties (COP21) summit of the United Nations Framework Convention on Climate Change held in Paris (2015), 195 nations agreed in principle to take actions limiting global warming to $1.5-2^{\circ} \mathrm{C}$ [1]. In an attempt to avoid exceeding this limit, nations drew up Intended Nationally Determined Contributions (INDC). Currently, however, there is a gap between the INDC commitments and the emission reductions really required to avoid warming of more than $2^{\circ} \mathrm{C}$ [2]. For the world to meet the $<2^{\circ} \mathrm{C}$ target, it is estimated that emissions should peak before 2030 and then reduce rapidly to zero [3]. Because of the very long time taken for atmospheric $\mathrm{CO}_{2}$ levels to decrease naturally, there is effectively a cap on the cumulative emissions allowable to stay within the limit, such that failure to reduce emissions short term will necessitate even more onerous commitments later on. This situation introduces doubts about whether the target is indeed achievable [4].

Such doubts have prompted researchers and policymakers to consider other approaches to avoid catastrophic climate change, beyond simply reducing emissions. In particular, removal of greenhouse gases (especially carbon dioxide) from the environment, is considered an increasingly relevant and important option. Technologies that achieve such removal, in some cases meeting other aims simultaneously, have been termed Negative Emissions Technologies (NETs) [4-7]. Broadly they include technologies that remove $\mathrm{CO}_{2}$ directly from the atmosphere (e.g. Direct Air Capture, DAC [8-11]; and Bioenergy and Carbon Capture and Storage, BECCS [12]) and those that remove $\mathrm{CO}_{2}$ via the hydrological cycle and oceans (e.g. Accelerated Weathering, AW [13, 14]; Ocean Liming and Alkalinisation [15-18]). With regard to the potential of the oceans to absorb $\mathrm{CO}_{2}$, a recent review by Renforth and Henderson has highlighted the very large capacity of this natural sink and therefore the importance of accelerating its uptake [18].

All these NETs would, however, require large commitments of infrastructure, capital equipment, and running costs. For example, accelerated weathering may demand mining and transportation of quantities of rock exceeding the mass of the $\mathrm{CO}_{2}$ removed, i.e. running into billions of tonnes per year in order to have a significant effect on atmospheric concentrations [13]. It is important therefore to compare NETs with regard to overall biophysical and economic limits $[5,7]$ - thus helping to assess whether they can make a significant and practical contribution to tackling climate change alongside more conventional approaches based on mitigation.

\subsection{Desalination as a Negative Emissions Technology}

Driven by the soaring demand for freshwater, seawater desalination is growing in capacity worldwide. Alongside this, its environmental impacts are growing also [19, 20]. Global capacity roughly doubled from 2007-2017 and is estimated at 100 million $\mathrm{m}^{3} /$ day output today [21]. The impacts result mainly from the substantial energy usage and associated $\mathrm{CO}_{2}$ emissions, and from the brine that desalination plants discharge to the ocean. On the other hand, seawater brine contains significant amounts of metal ions which have potential to combine with and sequester $\mathrm{CO}_{2}$ as carbonate or bicarbonate. 
A number of authors have investigated potential of brine from seawater to absorb $\mathrm{CO}_{2}$ through various combinations of process steps. For example, Ferrini et al. [22] showed that adding $\mathrm{CO}_{2}$ to magnesium chloride in the presence of ammonia precipitated magnesium carbonate as nesquehonite $\left(\mathrm{MgCO}_{3} \cdot 3 \mathrm{H}_{2} \mathrm{O}\right)$, producing ammonium chloride as a by-product. Nesquehonite could be used as a structural material for building, in the form or aggregate, concrete or cement. Benyahia [23] has proposed a process that reacts $\mathrm{CO}_{2}$ with sodium chloride, also in the presence of ammonia, to produce sodium bicarbonate. In this case, the by-product of ammonium chloride is regenerated by lime $(\mathrm{CaO})$ to give calcium chloride, releasing ammonia which is reutilised in the process. Indeed it is interesting to note that the Solvay process and Hou's process also involve similar steps to react $\mathrm{CO}_{2}$ with ammonia and sodium chloride [24].

Nonetheless, the above methods rely on a supply of pure or concentrated $\mathrm{CO}_{2}$ to the process, making them suited to absorption of $\mathrm{CO}_{2}$ from point sources such as flue stacks. They are not intended for removal of $\mathrm{CO}_{2}$ that has been diluted in the atmosphere and ocean; and would thus only be suitable for CDR if preceded by another process that captures and concentrates the diluted $\mathrm{CO}_{2}$. The above methods do not by themselves, therefore, constitute NET.

House et al. [17] identified that the chloralkali process could be used to render sodium chloride solution alkaline for addition to the oceans. The chloralkali process requires electrical energy, some of which can be recovered by reacting the evolved hydrogen and chlorine in a fuel cell. The resulting hydrochloric acid can be reacted with silicate rocks. This would be similar to accelerated weathering of rocks by carbonic acid, although hydrochloric acid will react with silicate rocks much more quickly than carbonic acid [25, 26]. House et al. [17] discussed the the application of such an alkalinisation process to seawater, but without discussing desalination brines specifically. They calculated electrical energy penalties in the range 100$400 \mathrm{~kJ} / \mathrm{molCO}_{2}\left(2.3-9.1 \mathrm{GJ} / \mathrm{tCO}_{2}\right)$.

A related approach is to convert the magnesium chloride in seawater brine to magnesium oxide or hydroxide, which has similar absorptive capacity for $\mathrm{CO}_{2}$ as calcium oxide as proposed for ocean liming. Magnesium (hydr)oxide may be obtained from magnesium chloride present in seawater and brine. The established technologies for doing so involve liming out the $\mathrm{MgO}$ by addition of alkaline substances. These accounted for about $70 \%$ of the 330000 tonnes of MgO produced in the US in 2017, while other sources were from mining of magnesite [27].

To produce $\mathrm{MgO}$ from brine using renewable energy, Davies [28] investigated the potential of solar thermal energy to convert magnesium chloride to magnesium oxide through decomposition at $300-600^{\circ} \mathrm{C}$. He concluded that the process is feasible in principle, but the energy consumption is high on account of the large latent heat of dewatering the brine before decomposition begins. Even though it should be possible to recover some of this latent heat, electrical and thermal energy consumptions (per gross tonne of $\mathrm{CO}_{2}$ removed) remain somewhat high at $0.8 \mathrm{GJ} / \mathrm{tCO}_{2}$ and $13 \mathrm{GJ} / \mathrm{tCO}_{2}$ respectively. As with the chloralkali process, hydrochloric acid arises as a by-product, and approaches to geological disposal were discussed [28].

Electrochemical treatment may be more promising than thermal treatment to alkalinise brine. Recently, advanced electrochemical methods have been developed to improve seawater brine electrolysis [29, 30]. Fernández-González et al. [29] used a bipolar membrane to decompose seawater brine into acids and bases, with the emphasis on the economic value of 
these products. Xie et al. [30] introduced a new way of decomposing magnesium chloride by an electrolysis process incorporating a gas diffusion anode (GDA), yielding magnesium hydroxide and hydrochloric acid. This process was intended to be used for Carbon Capture and Storage (CCS) of flue gases. Though neither of these electrochemical processes was intended for use as NET specifically, both studies imply the feasibility of creating a NET if the alkaline discharge is directed to the ocean. Among these two processes, the electrolysis-GDA method is particularly appealing in terms of its potentially low energy consumption and simpler configuration of the electrolysis cells. These would be the key factors in keeping both capital and operational costs low for large scale processing.

Building on these recent works, this study considers the conversion of desalination to a negative emissions technology (NET-desalination). It is proposed that the electrolysis-GDA be developed for continuous processing of brine at the outlet of existing or new desalination plants, to create magnesium hydroxide for discharge to the ocean. The main objective is to estimate the energy and water requirements of such NET-desalination, and to compare these penalties to the other NETs based on values provided in the literature $[5,15,28]$. The NETs chosen for comparison include BECCS, DAC, ocean liming and the choralkali process. Energy and water penalties are chosen as the main focus for the study, because they are considered fundamental in constraining the feasibility and scalability of the proposal. We also compare the specific energy consumption (per unit of freshwater produced) of the desalination plant, before and after adding the electrochemical process, to assess the preliminary feasibility of such a modification from the point of view of the operators of desalination plants whose primary objective is to provide freshwater to consumers.

This paper presents a theoretical and conceptual study, drawing on and comparing against results provided in the literature. First the electrolysis-GDA process will be considered, then the whole NET-desalination system including this process will be analysed in different cases to provide results and conclusions dependent on the input parameters and scope of the analysis.

\section{Analysis of the electrolysis-GDA process}

As electrolysis is energy-intensive, its energy requirement will be one of the key factors determining the feasibility in turning desalination into a NET. To determine the energy requirement, a thermodynamic analysis has been carried out to provide the minimum cell voltage of membrane electrolysis with GDA as shown in Figure 1. The electrolyser is of a flowthrough type with two compartments separated by an anion exchange membrane [30]. The left compartment has fresh water flowing in and hydrochloric acid flowing out. In the case of the right compartment, desalination reject brine flows in and magnesium hydroxide, suspended in the brine, flows out. The GDA allows hydrogen generated at the cathode to react with chloride ions, yielding hydrochloric acid as a by-product. 


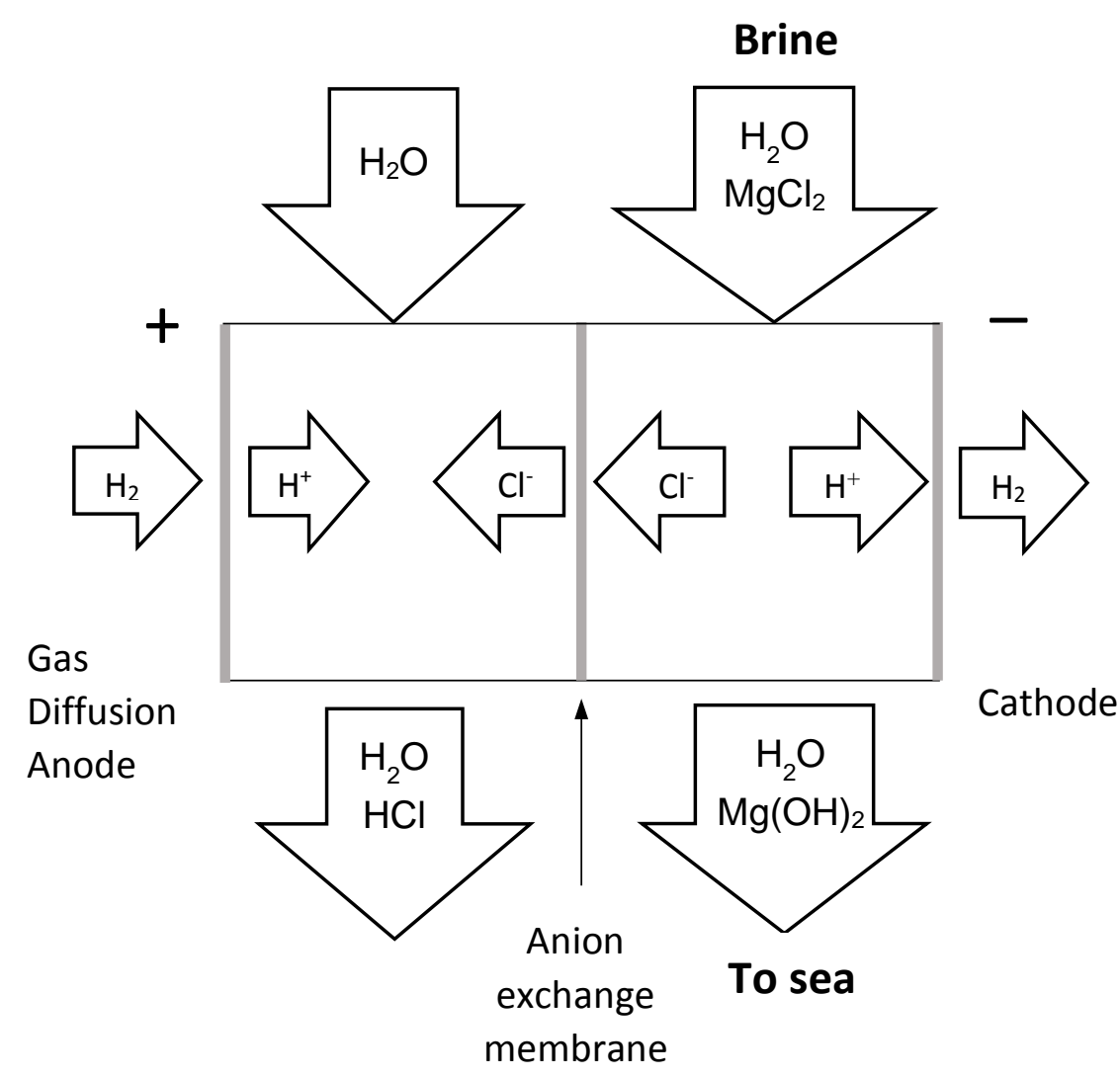

Figure 1: Illustration of electrolyser with gas diffusion anode (GDA) for splitting brine containing magnesium chloride into $\mathrm{HCl}$ and $\mathrm{Mg}(\mathrm{OH})_{2}$. Modified from [30].

With use of the GDA, the two half-cell reactions are:

$$
\begin{array}{ll}
\text { Cathode } & \mathrm{Mg}^{2+}(\mathrm{aq})+2 \mathrm{H}_{2} \mathrm{O}(\mathrm{l})+2 \mathrm{e} \rightarrow \mathrm{Mg}(\mathrm{OH})_{2}(\mathrm{~s})+\mathrm{H}_{2}(\mathrm{~g}) \\
\text { Anode } & \mathrm{H}_{2}(\mathrm{~g})+2 \mathrm{Cl}^{-}(\mathrm{l})-2 \mathrm{e} \rightarrow 2 \mathrm{HCl}(\mathrm{aq})
\end{array}
$$

The overall electrolysis reaction is accordingly:

$$
\mathrm{MgCl}_{2}(\mathrm{aq})+2 \mathrm{H}_{2} \mathrm{O}(\mathrm{I}) \rightarrow \mathrm{Mg}(\mathrm{OH})_{2}(\mathrm{~s})+2 \mathrm{HCl}(\mathrm{aq})
$$

Using the standard enthalpy and entropy of each component in this reaction equation, the enthalpy and Gibbs free energy change of the reaction at standard conditions have been calculated based on standard thermochemical data [31] as:

$$
\begin{aligned}
\Delta H^{\circ} & =114.06 \mathrm{~kJ} / \mathrm{mol} \\
\Delta \mathrm{G}^{\circ} & =95.73 \mathrm{~kJ} / \mathrm{mol}
\end{aligned}
$$

Converting these into voltages, we obtain thermo-neutral (adiabatic) and reversible voltages for the reaction as respectively:

$$
\begin{aligned}
& V_{\text {th }}=-\Delta H^{0} /(n F)=-0.59 \mathrm{~V} \\
& V_{\text {rev }}=-\Delta G^{0} /(n F)=-0.50 V
\end{aligned}
$$

where $\mathrm{F}$ is the Faraday constant $\left(\mathrm{F}=9.649 \times 10^{4} \mathrm{C} / \mathrm{mol}\right)$ and $\mathrm{n}$ is the number of moles of electrons transferred per mole of $\mathrm{Mg}^{2+}$ precipitated $(\mathrm{n}=2)$. 
When the working conditions differ from the standard ones, the voltage needed for the electrolysis will vary. The Gibbs free energy change under given working conditions can be calculated by means of the Nernst-type equation:

$$
\Delta G=\Delta G^{0}+R T \ln \left\{\frac{[\mathrm{HCl}]^{2}}{\left[\mathrm{MgCl}_{2}\right]}\right\}
$$

The concentration of the magnesium chloride in the brine will depend on the concentration of the incoming seawater and the recovery ratio of the plant. The rejection fraction of modern seawater desalination plants is very high $(>98 \%)$, such that virtually all the salts end up in the reject brine. Assuming standard practical salinity of 35 and density of $1027 \mathrm{~kg} / \mathrm{m}^{3}$, results in $\left[\mathrm{MgCl}_{2}\right]=0.05424 \mathrm{M}$ increased by the factor $1 /(1-r)$ according to the recovery ratio $\mathrm{r}$. At $25^{\circ} \mathrm{C}$, eq.(5) thus becomes (in units of $\mathrm{kJ} / \mathrm{mol}$ ):

$$
\Delta G=102.96+4.96 \ln [\mathrm{HCl}]+2.48 \ln (1-r)
$$

We note that seawater desalination plants typically operate in hot climates, taking in seawater at temperature in the range $15-35^{\circ} \mathrm{C}$ according to location and season. Therefore, $25^{\circ} \mathrm{C}$ is a representative assumption for temperature, especially since a change of $10^{\circ} \mathrm{C}$ will only alter the above Gibbs energy by about $0.3 \%$. The concentration $[\mathrm{HCl}]$ will evidently influence the energy consumption and values in the range $1-10 \mathrm{M}$ are considered.

The Gibbs free energy calculated by the Nernst equation represents an ideal minimum energy requirement of the electrolysis process under reversible isothermal conditions. But more realistically the cell may operate under adiabatic conditions requiring slightly greater voltage and work input. An efficiency $\eta$ is introduced to estimate the real energy consumption accounting for practical losses:

$$
\Delta G^{\prime}=\Delta G / \eta
$$

The cell electrolysis efficiency is estimated based on experimental evidence [30] where $\mathrm{V}=0.60 \mathrm{~V}$ was reported, close to the thermo-neutral potential of $\mathrm{V}_{\text {th }}=0.59 \mathrm{~V}$ and suggesting that an efficiency of $\eta=0.50 / 0.60=83.3 \%$ relative to $V_{\text {rev }}$ could be achieved. Accordingly, we assume a nominal efficiency of $\eta=80 \%$ in this study, with a range of $60-90 \%$ being considered as part of the sensitivity analsyis.

Magnesium hydroxide reacts stoichiometrically with $\mathrm{CO}_{2}$ in seawater to form magnesium carbonate:

$$
\mathrm{Mg}(\mathrm{OH})_{2}(\mathrm{~s})+\mathrm{CO}_{2} \rightarrow \mathrm{MgCO}_{3}+\mathrm{H}_{2} \mathrm{O}
$$

Further reaction to form magnesium bicarbonate absorbs in total of up to 2 moles of $\mathrm{CO}_{2}$ per mole of magnesium:

$$
\mathrm{MgCO}_{3}+\mathrm{H}_{2} \mathrm{O}+\mathrm{CO}_{2} \leftrightarrow \mathrm{Mg}\left(\mathrm{HCO}_{3}\right)_{2}
$$

Nonetheless, due to the reversible nature of this second reaction, the ratio achieved in practice is less than 2, estimated in the range 1.4 to 1.7 according to conditions of $\mathrm{CO}_{2}$ concentration, temperature, and salinity. Renforth and Henderson have calculated a ratio of 1.66 which is adopted in this study [18]. The energy per mole of $\mathrm{CO}_{2}$ to be removed will accordingly be $1 / 1.66=60 \%$ that calculated by Eq.(7).

We note that an alternative electrolysis process involving sodium chloride could in principle occur: 


$$
\mathrm{NaCl}(\mathrm{aq})+\mathrm{H}_{2} \mathrm{O}(\mathrm{I}) \rightarrow \mathrm{NaOH}(\mathrm{aq})+\mathrm{HCl}(\mathrm{aq})
$$

However, since the associated $\mathrm{V}_{\text {rev }}=-0.83 \mathrm{~V}$ is higher in magnitude than that for $\mathrm{MgCl}_{2}, \mathrm{Eq}$ (3) will proceed in preference.

\section{Analysis of the NET-desalination system}

The next step is the analysis of the desalination system including the electrolysis process. The system studied (Figure 2) consists of a state-of-the art reverse osmosis (RO) desalination plant, a power generation plant, and the concentrate brine electrolysing unit. The discharge of the desalination plant passes through the electrolyser, where $\mathrm{MgCl}_{2}$ in the brine is split into magnesium hydroxide suspension and hydrochloric acid, as described above. The magnesium hydroxide suspension discharged into the sea will absorb $\mathrm{CO}_{2}$.

The study comprises two cases each of different scope. Case 1 considers only the additional processes (inside the dashed box, Figure 2) of the NET-desalination relative to those of the unmodified plant. The NET modification requires additional inputs of electricity and freshwater, penalties that will be evaluated in relation to the $\mathrm{CO}_{2}$ absorbed to enable comparison with other NETs. Case 2 considers the whole system (entire Figure 2) to examine the net emission taking into account the operation of the desalination plant and associated power generation.

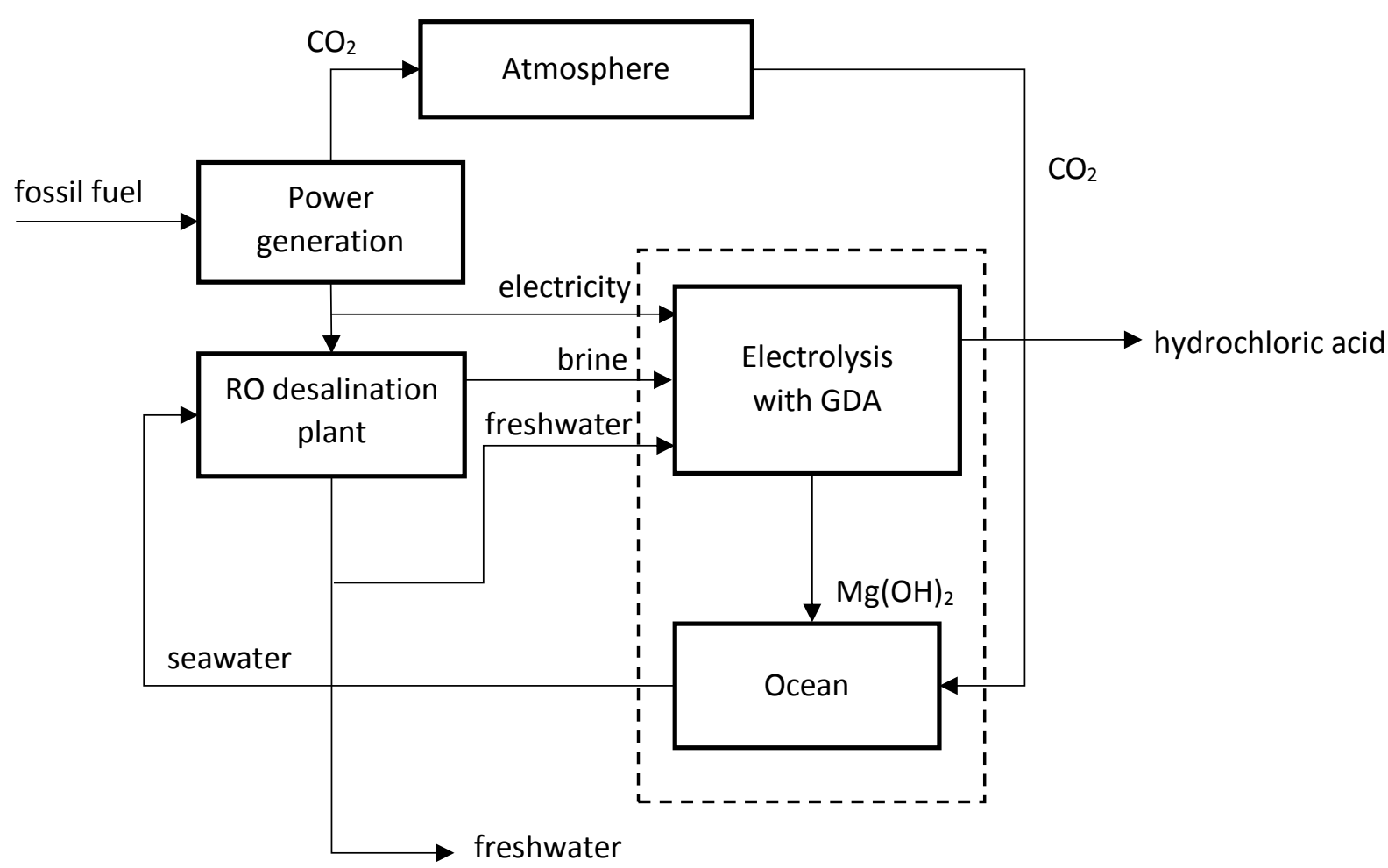

Figure 2: The system under study consists of a state-of-the art reverse osmosis $(\mathrm{RO})$ desalination plant with the brine discharge passing through an electrolysis unit. Case 1 considers only the processes inside the dashed box, whereas Case 2 considers the whole system. 
Case 1 is appropriate for assessing the benefits and penalties of electrolysis as an add-on to desalination plants already existing or planned, where the energy consumption of the desalination plant is not counted as a penalty of the NET - because this penalty is considered unavoidable in the sense that it would occur anyway even if the NET-modification were not implemented.

Case 2 would be more appropriate if the energy consumption of the desalination plant is not considered unavoidable. For example, the NET aspect might be used as a partial justification for building new desalination plants - helping to favour desalination over other ways to meet increased water demand (e.g. water transfers, increased water re-use, or demand side measures). Then, arguments, against desalination would most likely point to the overall penalties, and not just the additional ones of NET modification. The same scope would apply if in the future there was a decision to be made about whether to continue to operate a NETdesalination plant or replace it with alternative systems to provide the same services.

Because it includes the whole system, case 2 is also useful to compare how the specific energy consumption (SEC, per unit of freshwater output) of desalination compares with and without NET. This will require assumptions to be made about the energy consumption of the desalination plant and the carbon-intensity of electricity generation powering the system. Case 2 is also useful for making preliminary comparisons with other NET where there are additional valuable outputs to consider. Thus, BECCS is not just a system for removing $\mathrm{CO}_{2}-$ it is also a system for providing an energy service. Similarly, NET-desalination is intended not only to remove $\mathrm{CO}_{2}$ but also to provide clean water.

Note that in neither case do we consider the emissions, energy or water penalties associated with construction of the plant. Only operational penalties are considered. This is because it is typically stated that energy during operation is the dominant contribution to costs and, by extension, emissions [32]. The land usage of a desalination plant is assumed very small (compared to, say, BECCS) and considered negligible. The brine input is not considered as a penalty, because brine is considered a waste product from the desalination plant.

Cases 1 and 2 enable different questions to be answered regarding negative emissions, as summarised in Table 1. 
Table 1: Scope and purpose of the two cases analysed.

\begin{tabular}{|c|c|c|}
\hline & \multicolumn{2}{|r|}{ Case } \\
\hline & 1. NET modification only & 2. Whole system \\
\hline $\begin{array}{l}\text { Electrolysis add-on } \\
\text { to desalination } \\
\text { plant for brine } \\
\text { treatment }\end{array}$ & Included & Included \\
\hline Desalination plant & Excluded & Included \\
\hline $\begin{array}{l}\text { Power generation } \\
\text { and emissions for } \\
\text { desalination plant }\end{array}$ & Excluded & Included \\
\hline $\begin{array}{l}\text { Questions that can } \\
\text { be answered: }\end{array}$ & $\begin{array}{l}\text { 1. If brine treatment } \\
\text { is added to } \\
\text { existing } \\
\text { desalination } \\
\text { plants, or to plants } \\
\text { that will be built } \\
\text { anyway, how does } \\
\text { it compare to other } \\
\text { types of NET } \\
\text { taking into account } \\
\text { only the additional } \\
\text { inputs required? }\end{array}$ & $\begin{array}{l}\text { If new desalination plants are built with brine } \\
\text { treatment included: } \\
\text { 1. Could they provide negative emissions } \\
\text { (NET)? } \\
\text { 2. How does the system as a whole compare to } \\
\text { an unmodified desalination plant? } \\
\text { 3. How does the system as a whole compare to } \\
\text { other types of NET taking into account the } \\
\text { additional outputs in each case e.g. water and } \\
\text { energy services? } \\
\text { In this case all inputs and outputs should be } \\
\text { included, and not just the additional ones } \\
\text { associated with the electrolytic brine treatment. }\end{array}$ \\
\hline
\end{tabular}

Table 2 summarises the values of baseline parameters used in this study as well as their ranges for the sensitivity analysis. For the whole system (Case 2), input parameters include the specific energy consumption (SEC) of the RO desalination plant, and the carbon intensity associated with the energy supply. For the SEC, we assume a nominal value of $3 \mathrm{kWh} / \mathrm{m}^{3}$ representing a modern state-of-the art plant [33]. In addition, we consider sensitivity to SEC in the range $1-4 \mathrm{kWh} / \mathrm{m}^{3}$. The lower limit of $1 \mathrm{kWh} / \mathrm{m}^{3}$ corresponds approximately to the thermodynamic minimum possible SEC [34]; while $4 \mathrm{kWh} / \mathrm{m}^{3}$ may be a representative figure for a plant with slightly elevated energy requirements due, for example, to the need to cope with more difficult feedwater, thus requiring more treatment stages [32].

For the carbon intensity, we use a baseline figure of $0.5 \mathrm{kgCO}_{2}$ per $\mathrm{kWh}$ of electricity generated - corresponding to efficient electricity generation by relatively clean fossil fuel in the form of natural gas $[35,36]$. To provide a sensitivity analysis, we consider also values in the range 0 and $1 \mathrm{kgCO}_{2} / \mathrm{kWh}$ respectively, corresponding respectively to ideal zero-carbon generation from renewables and to more carbon intensive generation by fossil fuel (e.g. coal instead of gas). The recovery ratio of the plant is taken as 0.5 , with a range 0.4 to 0.8 also considered (Table 2). 
Table 2: Assumed baseline values and ranges of parameters used in this study. The baseline values apply by default to the results.

\begin{tabular}{|c|c|c|c|}
\hline & Baseline value & Range & Notes and sources \\
\hline Density of seawater & $1027 \mathrm{~kg} / \mathrm{m}^{3}$ & - & Typical value from ref [37] \\
\hline $\begin{array}{l}\text { Concentration of } \\
\text { magnesium in } \\
\text { seawater }\end{array}$ & $\begin{array}{l}1.2837 \mathrm{~g} / \mathrm{kg} \\
0.05424 \mathrm{M}\end{array}$ & - & $\begin{array}{l}\text { Millero et al [38], for standard } \\
\text { seawater at practical salinity of } \\
35\end{array}$ \\
\hline $\begin{array}{l}\text { Temperature of } \\
\text { seawater }\end{array}$ & $25^{\circ} \mathrm{C}$ & - & $\begin{array}{l}\text { Desalination plants typically } \\
\text { take in water at } 15-35^{\circ} \mathrm{C}[21]\end{array}$ \\
\hline $\begin{array}{l}\text { Efficiency of } \\
\text { electrolysis process }\end{array}$ & 0.8 & $0.6-0.9$ & $\begin{array}{l}\text { Xie et al [30] (see discussion in } \\
\text { section 4) }\end{array}$ \\
\hline $\begin{array}{l}\text { Concentration } \\
\text { hydrochloric acid at } \\
\text { outlet }\end{array}$ & $2 M$ & $1-10 \mathrm{M}$ & See ref [29]. \\
\hline $\begin{array}{l}\text { Specific energy } \\
\text { consumption (SEC) } \\
\text { of basic RO plant }\end{array}$ & $\begin{array}{l}3 \mathrm{kWh} / \mathrm{m}^{3} \\
\left(10.8 \mathrm{MJ} / \mathrm{m}^{3}\right)\end{array}$ & $1-4 \mathrm{kWh} / \mathrm{m}^{3}$ & $\begin{array}{l}\text { Per } \mathrm{m}^{3} \text { of freshwater produced. } \\
\text { Typical practical value for state- } \\
\text { of-art RO plant [33]. Specific } \\
\text { examples in the literature refer } \\
\text { to values as low as } 2 \mathrm{kWh} / \mathrm{m}^{3} \\
\text { [39]; with other plants reporting } \\
\text { closer to } 4 \mathrm{kWh} / \mathrm{m}^{3} \text { [21]. } 1 \\
\mathrm{kWh} / \mathrm{m}^{3} \text { approximates a } \\
\text { thermodynamic minimum [34]. }\end{array}$ \\
\hline $\begin{array}{l}\text { Carbon intensity of } \\
\text { electricity } \\
\text { generation }\end{array}$ & $0.5 \mathrm{kgCO}_{2} / \mathrm{kWh}$ & $0-1 \mathrm{kgCO}_{2} / \mathrm{kWh}$ & $\begin{array}{l}0.5 \text { is a nominal value of } \\
\text { generation based on natural gas } \\
{[35,36] \text { : range represents 'ideal }} \\
\text { zero-carbon renewables' to } \\
\text { 'high-carbon fossil fuel'. }\end{array}$ \\
\hline Recovery ratio (r) & 0.5 & $0.4-0.8$ & $\begin{array}{l}\text { RO desalination plants typically } \\
\text { operate in the range } 0.4 \text { to } 0.5 \\
\text { though higher recoveries are } \\
\text { possible with higher energy } \\
\text { expenditure [32]. }\end{array}$ \\
\hline
\end{tabular}

We also consider the effect of varying the recovery ratio $r$ of the $\mathrm{RO}$ plant around the baseline value of 0.5 . The effect on SEC is modelled by assuming that SEC varies in constant proportion to the minimum thermodynamic energy of desalination [40], i.e.

$$
S E C=2.164 \frac{1}{r} \ln \left[\frac{1}{1-r}\right] \quad(\mathrm{kWh})
$$

With the constant of $2.164 \mathrm{kWh} / \mathrm{m}^{3}$ chosen such that $\mathrm{SEC}=3 \mathrm{kWh} / \mathrm{m}^{3}$ at $r=0.5$. 


\section{Results}

The results in this section use the baseline values of Table 2 unless stated otherwise. Calculated results for the penalties of energy, water and land for cases 1 and 2 are presented in Table 3, compared against results (from the literature) for other NET options.

Table 3: NET-desalination using electrolysis of brine with GDA, against other options presented in the literature.

\begin{tabular}{|c|c|c|c|c|c|}
\hline \multirow{2}{*}{ NET option } & \multirow{2}{*}{ Reference } & \multicolumn{2}{|c|}{$\begin{array}{l}\text { Energy penalty } \\
\left(\mathrm{GJ} / \mathrm{tCO}_{2}\right)\end{array}$} & \multirow{2}{*}{ 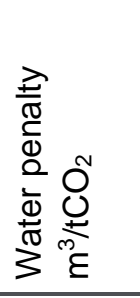 } & \multirow[b]{2}{*}{ 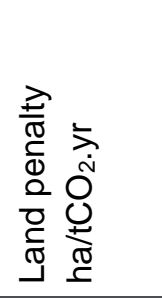 } \\
\hline & & $\begin{array}{l}\overline{\widetilde{J}} \\
\stackrel{\frac{\Phi}{\Phi}}{\risingdotseq} \\
\stackrel{F}{F}\end{array}$ & 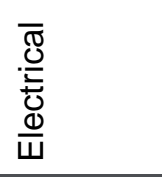 & & \\
\hline $\begin{array}{l}\text { NET-Desalination (brine } \\
\text { electrolysis with GDA): } \\
\text { Case } 1, \text { NET-modification only }\end{array}$ & This study & 0 & 1.8 & 13.7 & negligible \\
\hline $\begin{array}{l}\text { NET-Desalination (brine } \\
\text { electrolysis with GDA): } \\
\text { Case 2, whole system }\end{array}$ & This study & 0 & 5.6 & -206 & negligible \\
\hline Chloralkali process & [17] & 0 & $2.3-9.1$ & no data & negligible \\
\hline $\begin{array}{l}\text { NET-Desalination (brine } \\
\text { thermal decomposition) }\end{array}$ & [28] & 13 & 0.8 & 0 & negligible \\
\hline Ocean liming & [15] & $\begin{array}{l}0.6- \\
5.6\end{array}$ & $0.1-1.2$ & $0.5-1.2$ & no data \\
\hline $\begin{array}{l}\text { Crop Bio-energy + CCS } \\
\text { (BECCS) }\end{array}$ & [5] & & to -24 & 500 & $\begin{array}{l}270- \\
1600\end{array}$ \\
\hline Direct Air Capture (DAC) & [5] & & -12.5 & 25 & 1.5 \\
\hline
\end{tabular}



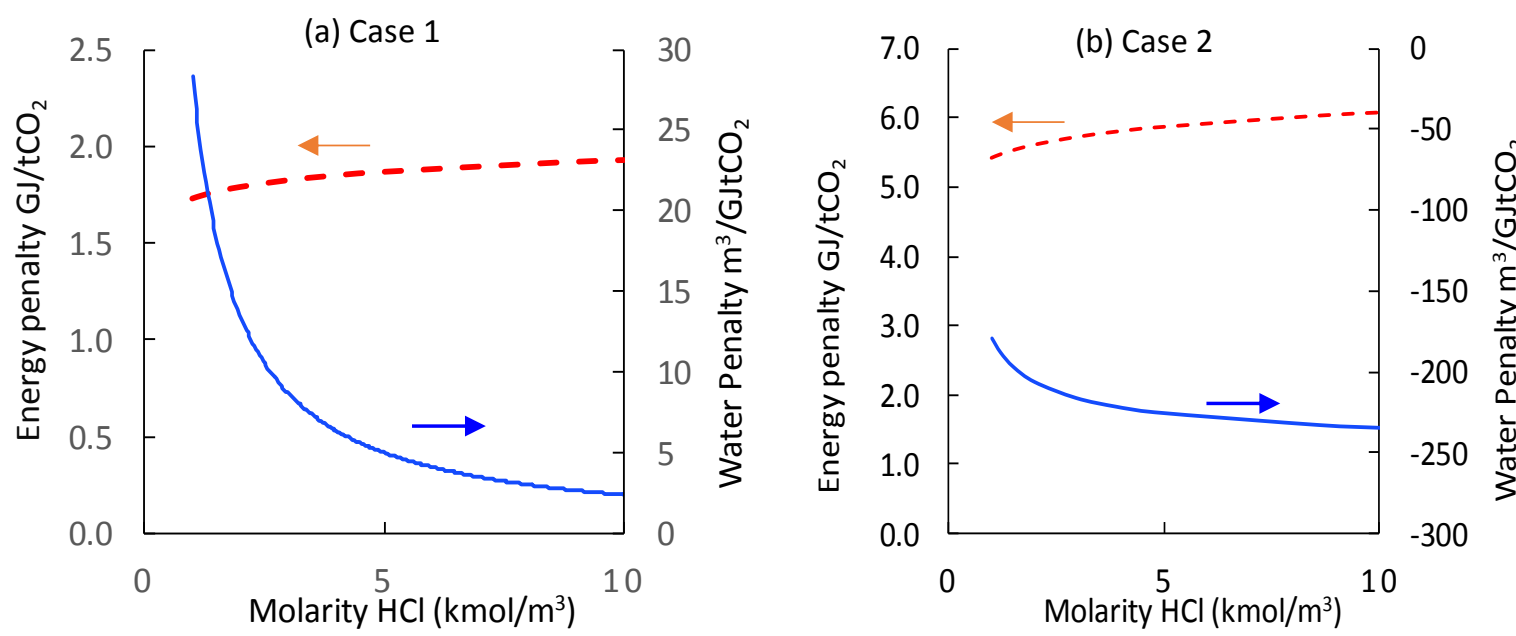

Figure 3: Sensitivity of energy and water penalties to concentration of hydrochloric acid discharged: higher concentration saves water but requires more energy (Case 1 and Case 2)

\subsection{Case 1: NET modification only}

In this case, the energy penalty is predicted as $1.8 \mathrm{GJ} / \mathrm{tCO}_{2}$ and water penalty as $13.7 \mathrm{~m}^{3} / \mathrm{tCO}_{2}$. The concentration of hydrochloric acid discharged has a small effect on energy penalty (Fig 3a) but a large effect on water penalty (Fig 3a) which goes down to $2.2 \mathrm{~m}^{3} / \mathrm{tCO}_{2}$ at $10 \mathrm{M}$. This is because less water is used to carry away the $\mathrm{HCl}$ at higher concentrations. Nonetheless, the review of Fernández-González et al. [29] suggests that a concentration above 2M is rarely achieved in practice. This could be attributed to the difficulty of overcoming back diffusion of chloride ions against the steep concentration gradient across the anion exchange membrane.

Nevertheless, this water penalty compares generally well with the more widely studied options of DAC and BECCS (Table 3). The value of $13.7 \mathrm{~m}^{3} / \mathrm{tCO}$ at $2 \mathrm{M} \mathrm{HCl}$ is about half the water penalty of DAC, and less than 3\% that of BECCS. However, it appears to be over 10 times higher than the water penalty estimated for ocean liming [15]. The previously studied option of brine thermal decomposition [28] does not incur any such water penalty (in fact water is recovered from the decomposition process); whereas in the current proposal, about $10 \%$ of the desalinated output is sacrificed for the electrolysis process; this means that a desalination plant with initial recovery $50 \%$ would achieve a reduced recovery of $45 \%$ after NET modification, with $\mathrm{HCl}$ produced at $2 \mathrm{M}$.

As regards energy penalty, the result of $1.8 \mathrm{GJ} / \mathrm{tCO}$ falls within the rather large range quoted for DAC ( 0.7 to $12.5 \mathrm{GJ} / \mathrm{tCO}_{2}$ ). The DAC figures do not distinguish between thermal and electrical energy penalty. However, such a distinction is available for ocean liming, suggesting that electrolysis-GDA is disadvantageous as regards electrical energy penalty (1.8 vs 0.1-1.2 $\mathrm{GJ} / \mathrm{tCO}_{2}$ ); but it avoids altogether the rather high thermal energy associated with ocean liming (up to $5.6 \mathrm{GJ} / \mathrm{tCO}_{2}$ ). Similarly it avoids the even higher thermal energy penalty of up to 13 $\mathrm{GJ} / \mathrm{tCO}_{2}$ associated with brine thermal decomposition for NET-desalination [28]. Nonetheless, 
all options including the electrolysis-GDA have worse energy penalty than BECCS, because BECCS is designed as an energy-producing system thus having negative energy penalty.

The energy penalty varies in inverse proportion to the efficiency of the electrolysis process. If the efficiency goes down from the $80 \%$ baseline to $60 \%$, the penalty will go up from 1.8 to 2.4 $\mathrm{GJ} / \mathrm{tCO}_{2}$. Water penalty is, however, unaffected.

Compared to the chloralkali process [17], which may be considered the most similar option to the current one among those described in the literature, we calculate a significant lowering of energy penalty (by a factor of about 1.5-5) using electrolysis-GDA. This is consistent with the value $\mathrm{V}_{\text {rev }}=-2.19 \mathrm{~V}$ of the reversible cell potential associated with the chloralkali process:

$$
\mathrm{NaCl}(\mathrm{aq})+2 \mathrm{H}_{2} \mathrm{O}(\mathrm{l}) \rightarrow \mathrm{NaOH}(\mathrm{aq})+\mathrm{H}_{2}(\mathrm{~g})+\mathrm{Cl}_{2}(\mathrm{~g})
$$

which is as such more than four times greater than $\mathrm{V}_{\text {rev }}$ associated with Eq.(3).

\subsection{Case 2: Whole system}

Expansion of the scope of the analysis to include the whole system, and not just the NETmodification, increases the overall electrical energy penalty $\sim 3$-fold to $5.6 \mathrm{GJ} / \mathrm{tCO}_{2}$ with the energy to run the RO process now included. Nonetheless, this penalty is still in the range reported for DAC. Since desalination produces net water output, with the desalination plant included the water penalty becomes negative at $-206 \mathrm{~m}^{3} / \mathrm{tCO}_{2}$. The whole desalination plant (including associated power generation and NET-modification) provides overall negative emissions at $-5 \mathrm{kgCO}_{2}$ per $\mathrm{m}^{3}$ of net water output (Figure 4). This compares with positive emissions of $1.5 \mathrm{kgCO} / \mathrm{m}^{3}$ for an unmodified desalination plant. As in case 1 , similar comments apply about the effect of $[\mathrm{HCl}]$ which would improve the water output still further if increased but with a slight adverse effect on energy penalty (Figure 3b).

With regard to the effect of carbon intensity, running the plant from zero-emissions renewables improves the net emissions still further to $-8.9 \mathrm{kgCO}_{2} / \mathrm{m}^{3}$. Considering that renewables have a finite emission due to embodied energy (reported intensities are in the range of $0.029-0.045$ $\mathrm{kgCO}_{2} / \mathrm{kWh}$ for monocrystalline silicon PV [41] and $0.006-0.046 \mathrm{kgCO}_{2} / \mathrm{kWh}$ for wind energy [42]) we predict more realistically about $-8.5 \mathrm{kgCO}_{2} / \mathrm{m}^{3}$. Even if the plant is run from carbonintensive coal-fired generation, emissions remain negative at around $-1 \mathrm{kgCO}_{2} / \mathrm{m}^{3}$ (Figure 4). 


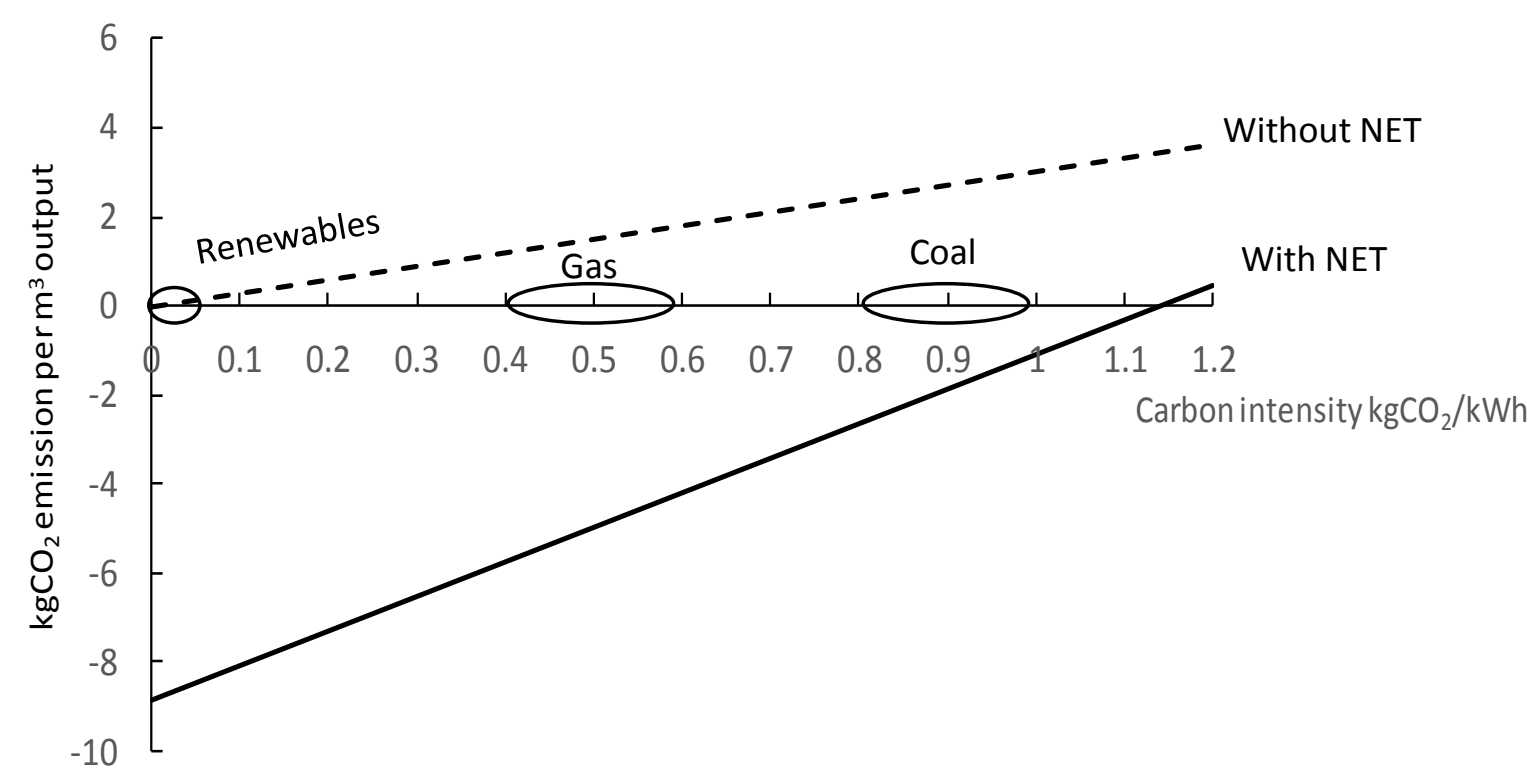

Figure 4: Comparison of desalination with and without NET modification using the electrolysis-GDA process (Case 2). Net emissions per net water output $\left(\mathrm{kgCO}_{2} / \mathrm{m}^{3}\right)$ increase with the carbon intensity of the electricity used, the values of which encompass generation from renewables, cleaner fossil fuel (gas), and high-carbon fossil fuel (coal) respectively.

NET-desalination incurs a considerable energy penalty when a direct comparison is made to an unmodified plant. If, as assumed here, all water brine output from the desalination plant is diverted to the electrolysis-GDA cell for full conversion of $\mathrm{MgCl}_{2}$ into $\mathrm{Mg}(\mathrm{OH})_{2}$ this will more than double the electricity consumption of the plant; and - if all the energy penalty is accounted for against the freshwater output - this will result in a SEC increased from 3 to $7.8 \mathrm{kWh} / \mathrm{m}^{3}$ (Figure 5, at basic SEC of $3 \mathrm{kWh} / \mathrm{m}^{3}$ ). Figure 6 shows that lower overall SEC is achieved at higher $\mathrm{HCl}$ concentrations, though above $2 \mathrm{M}$ the dependence is weak, such that at $10 \mathrm{M}$ the SEC reduces by only $5 \%$ to $7.4 \mathrm{kWh} / \mathrm{m}^{3}$. On the other hand, improved RO technology with basic SEC of $2 \mathrm{kWh} / \mathrm{m}^{3}$ reduces overall SEC after modification to $6.6 \mathrm{kWh} / \mathrm{m}^{3}$ (Figure 5). 


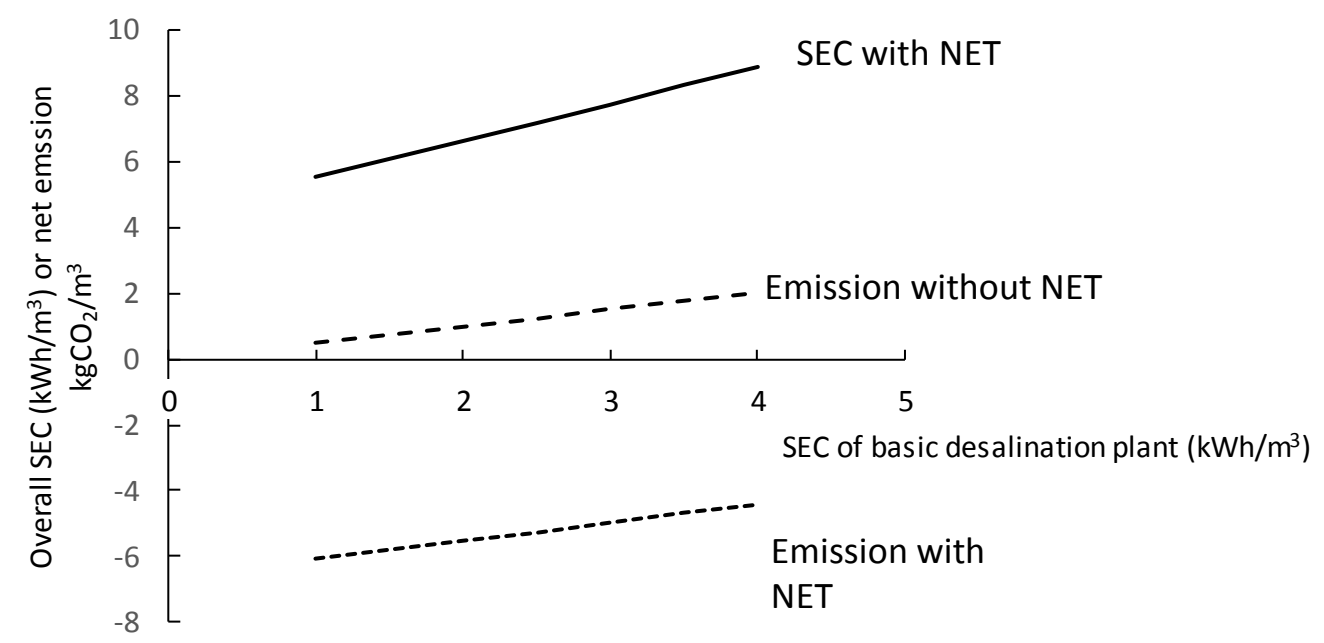

Figure 5: Dependence of the overall SEC after modification (case 2), and negative emissions achieved per net $\mathrm{m}^{3}$ of water output, on the SEC of the basic desalination plant before modification.

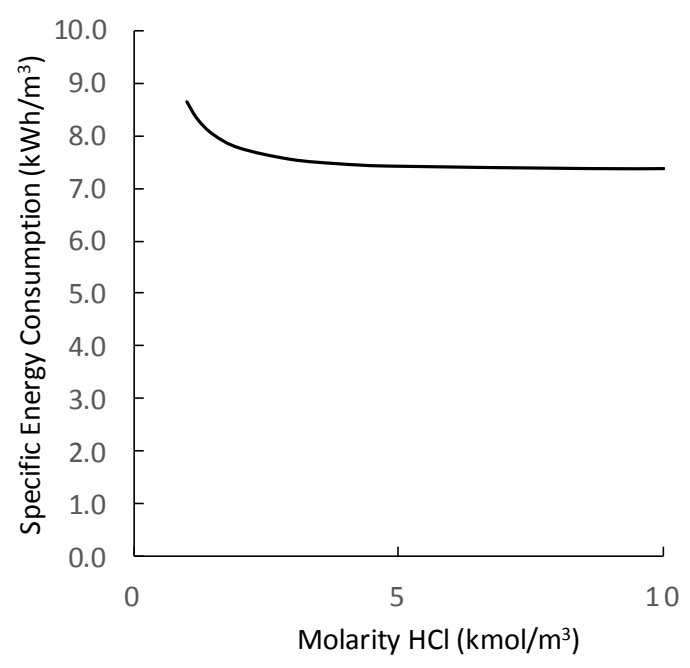

Figure 6: Specific Energy Consumption of the NET-desalination plant decreases with the concentration of the hydrochloric acid produced, due to lower sacrifice of water at higher concentrations, but is always much higher than that of a standard desalination plant $\left(\mathrm{SEC}=3 \mathrm{kWh} / \mathrm{m}^{3}\right)$.

The efficiency of the electrolysis process also has a significant effect on the results. As shown in Figure 7, if the electrolysis were $60 \%$ efficient (as opposed to the $80 \%$ baseline value) the negative emissions achieved would be only $-4.25 \mathrm{kgCO} / \mathrm{m}^{3}$ instead of $-5 \mathrm{kgCO} / \mathrm{m}^{3}$ and SEC increases to $9.2 \mathrm{kWh} / \mathrm{m}^{3}$. 


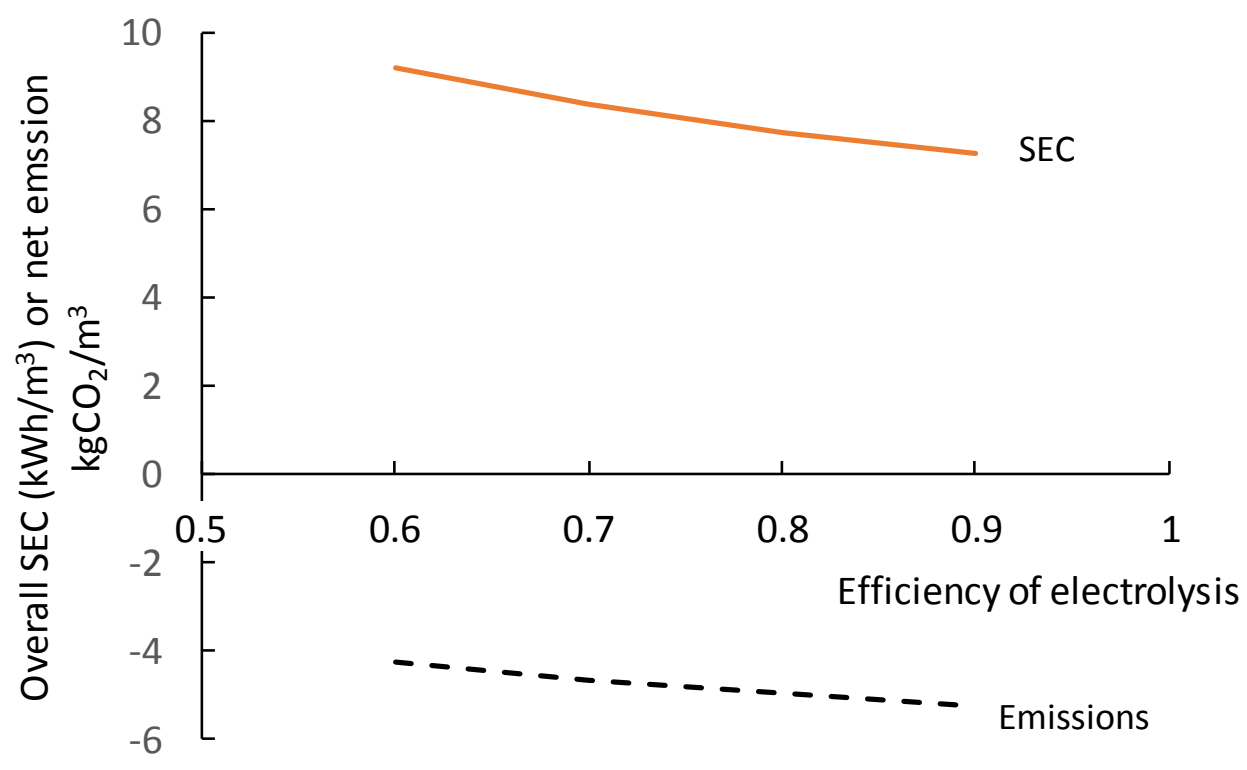

Figure 7: Increasing the efficiency of the electrolysis process improves both SEC and the negative emissions achieved by the modified desalination plant.

Increase in the recovery ratio of a RO plant normally results in increased SEC due to the increased osmotic pressure of the exiting brine. However, this trend is offset by the decreased electrical demand to electrolyse the brine based on the Nernst equation (Eq.5). Figure 8 shows a minimum SEC of $7 \mathrm{kWh} / \mathrm{m}^{3}$ occurring at recovery $r=0.7$. On the other hand, with the ratio of freshwater to brine increasing, the higher recovery ratio actually increases the total energy penalty of $\mathrm{CO}_{2}$ removal, such that the emission per $\mathrm{m}^{3}$ of water output becomes less negative. This suggests that the higher recovery ratio operation is only justified when the priority is to lower SEC and not to maximise performance as a NET. It is not possible to determine a true optimum without introducing some cost model including value of the water produced and cost penalty of carbon emission. 


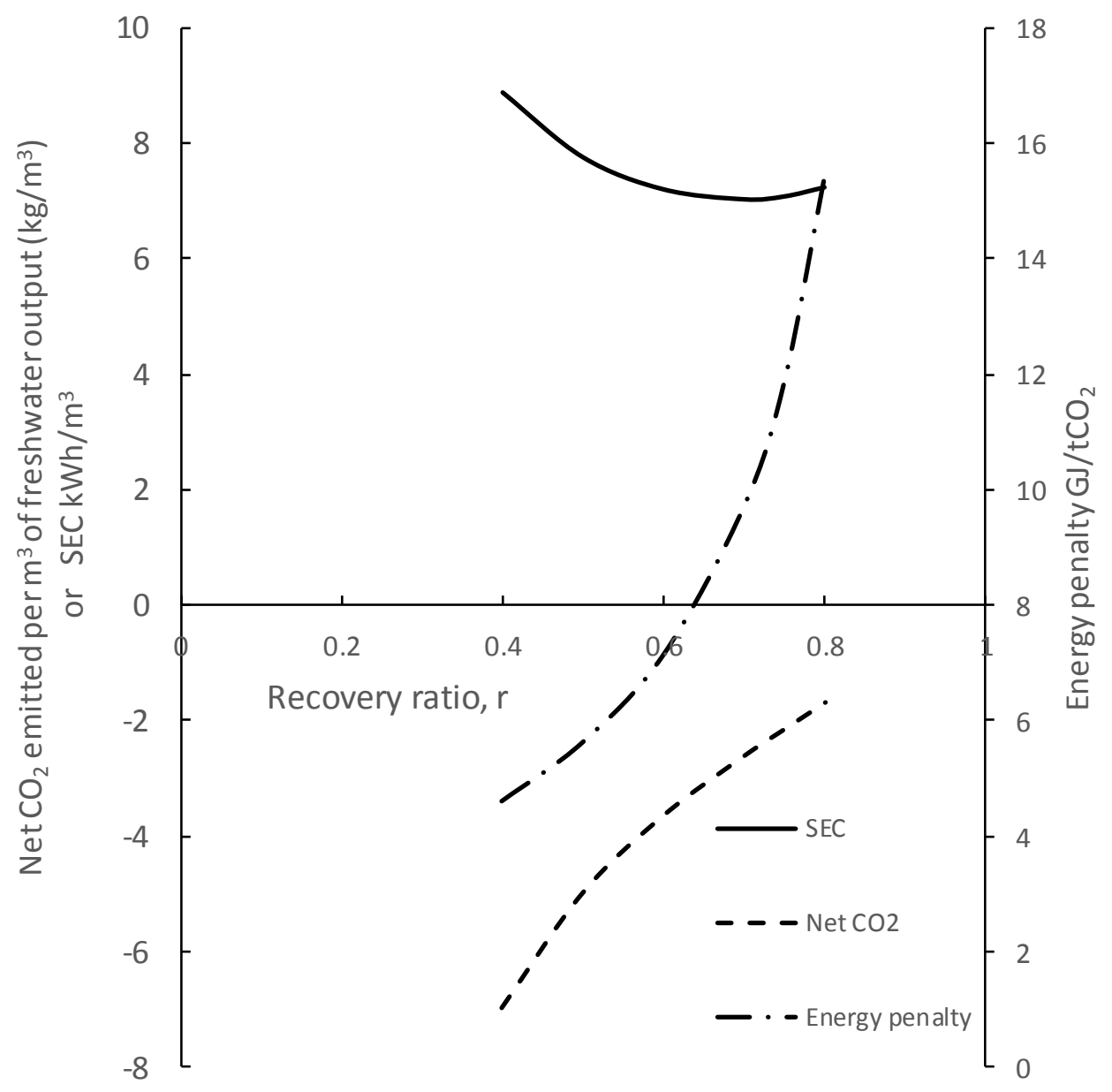

Figure 8: Effect of recovery ratio on SEC, net $\mathrm{CO}_{2}$ emitted per net $\mathrm{m}^{3}$ of freshwater produced, and energy penalty of $\mathrm{CO}_{2}$ removal - for the whole system of Figure 2 (Case 2).

To put these values in the context of a real desalination plant, we cite the example of the Carlsbad plant commissioned in 2015 in San Diego Country, United States. This plant has a freshwater output of $204390 \mathrm{~m}^{3} /$ day, taking in feedwater with $34,500 \mathrm{mg} / \mathrm{L}$ Total Dissolved Solids, and has recovery $r=0.5$. The energy consumption is cited as $<3.3 \mathrm{kWh} / \mathrm{m}^{3}$ [21]. In these respects, the plant conforms quite closely to the baseline parameters used in this study. Electricity generated in the State of California is, however, relatively low carbon at 0.24 $\mathrm{kgCO}_{2} / \mathrm{kWh}$, coming primarily from natural gas, with large contributions also from hydroelectric, solar, wind and geothermal. From Figure 4, the net emissions per $\mathrm{m}^{3}$ will correspondingly be $-7 \mathrm{kgCO}_{2} / \mathrm{m}^{3}$ - i.e. about $1.4 \mathrm{ktCO}_{2} /$ day and $500 \mathrm{ktCO}_{2} / \mathrm{yr}$.

To speculate on the future potential of NET-desalination, we could suggest a doubling of the current global desalination capacity of the 100 million $\mathrm{m}^{3} /$ day with all the new plants being installed to the specifications of the Carlsbad plant (i.e. a further 500 such plants) with the electrolysis units added, absorbing altogether $0.25 \mathrm{GtCO}_{2} / \mathrm{yr}$. If desalination continues to grow at an exponential rate, removal of of $1 \mathrm{GtCO}_{2} / \mathrm{yr}$ appears plausible by mid-century - thus potentially making a small but significant contribution to the required total removal rate 
estimated at 10-20 $\mathrm{GtCO}_{2} / \mathrm{yr}$ to stay within the Paris COP21 targets [4]. It should be noted that the scalability to meet desired targets is a difficult challenge for all NETs and not only for NET-desalination as proposed here [43].

\section{Discussion}

The calculated energy penalty of about $1.8 \mathrm{GJ} / \mathrm{tCO}_{2}$ for the NET-desalination modification, besides comparing quite well against other NET, compares favourably against other carbon abatement measures such as injecting renewable electricity to the grid. Substitution of fossilfuel based generation of grid power (at carbon intensity of $0.5 \mathrm{kgCO}_{2} / \mathrm{kWh}$ ) by renewables (at nominally zero carbon intensity) provides carbon abatement with an energy penalty of 7.8 $\mathrm{GJ} / \mathrm{tCO}$, suggesting that it would be 4 times better to use renewable energy in the electrolysisGDA process compared to grid injection for fossil fuel saving. If, however, we have to introduce a new desalination plant (and not just modify an existing one), the corresponding ratio will be decreased from 4 to just 1.4 taking into account extra emissions associated with the new plant.

A possible objection to the current proposal is that, by absorbing $\mathrm{CO}_{2}$ from the ocean, we introduce a long delay of many decades before this $\mathrm{CO}_{2}$ is absorbed from the atmosphere because of the relatively slow mixing between these two compartments [44]. If additional fossil fuel is burnt to power NET-desalination, $\mathrm{CO}_{2}$ will be emitted in the short term to achieve a predicted longer term absorption effect as regards the atmosphere. This time lag is undesirable, because global warming could be intensified in the short term. Therefore, the authors believe that, if NET-desalination is introduced, it must be powered renewably to achieve negative net emissions with nearly zero gross emissions. Alternatively, the NETdesalination technology could incorporate capture at source of $\mathrm{CO}_{2}$ emissions from associated fossil power generation, by reacting flue gases with the $\mathrm{Mg}(\mathrm{OH})_{2}$ on site as in [30], thus achieving negative net emissions even without use of renewables.

This time lag can also be used as an argument in favour of NET-desalination against atmospheric removal (e.g. DAC) as regards ocean acidification (a secondary effect of $\mathrm{CO}_{2}$ accumulation). NET-desalination could deliver a relatively rapid neutralisation effect and this should be explored with regard to relatively confined seas, such as the Mediterranean, Red Sea, or Gulf, where many desalination plants are already installed - giving prospects to provide local remediation of acidification over relatively short time scales on account of the smaller volume of seawater to be processed compared to the open oceans. In fact, it is also notable that desalination may currently contribute to ocean acidification because acid is used as anti-scalant to prevent carbonate precipitation on $\mathrm{RO}$ membranes [32]. As NETdesalination with electrolysis produces $\mathrm{HCl}$, this could be recycled to the inlet of the plant for this purpose, with neutralisation subsequently occurring at the outlet.

Another important objection relates to the disposal or management of the hydrochloric acid produced by the process. For every 1.66 moles of gross $\mathrm{CO}_{2}$ absorbed, 2 moles of $\mathrm{HCl}$ are produced - corresponding to a 1:1 mass ratio. With about 100 litres of $2 \mathrm{M}$ hydrochloric acid produced per $\mathrm{m}^{3}$ of desalinated water, the Carlsbad case above would produce about $8 \mathrm{Mt} / \mathrm{yr}$ of acid per year containing $0.6 \mathrm{Mt} / \mathrm{yr} \mathrm{HCl}$. The world market for $\mathrm{HCl}$ is estimated at $20 \mathrm{Mt} / \mathrm{yr}$; however, much of this is met by production close to the point of use, such that the open market demand is only about $5 \mathrm{Mt} / \mathrm{yr}$ [45]. As the conventional production of hydrochloric acid is in itself energy intensive, its substitution could provide an additional carbon benefit [28]. Nevertheless, scale up of the NET desalination concept would saturate the world market - 
besides which the logistics and hazards of moving around such large quantities of acid are daunting.

The most promising solution would seem to be geological disposal of hydrochloric acid by injection into silicate rocks that can neutralise it. It turns out that several silicate rock formations are available in the vicinity of desalination plants, e.g. the Samail ophiolite in Oman and Troodos ophiolite in Cyprus, as well as laval outflows of mafic rocks towards the Red Sea coast in Saudi Arabia [28]. Of related interest are studies on recycling of acids including hydrochloric acid into silicate rocks, extracting $\mathrm{MgCl}_{2}$ for splitting into $\mathrm{Mg}(\mathrm{OH})_{2}$ and $\mathrm{HCl}$ on site [46]. The energy requirements for electrolysis should be similar to those here, while the need for $\mathrm{HCl}$ transport is avoided; however, the reverse logistics of transport and ocean distribution of $\mathrm{Mg}(\mathrm{OH})_{2}$ would then need to be addressed. Concepts incorporating the silicate minerals (wollastonite or ultramafic rock) directly into an electrolytic process (also generating hydrogen fuel) have also been investigated [47].

Even though the use of renewable electricity for future $\mathrm{CO}_{2}$ removal benefit may seem expensive and hard to justify on account of the increased SEC of the desalination plant (more than doubled), it is worth pointing out that NET-desalination also provides a readily deferrable load such that brines may be readily stored for use in the electrolysis process that can be switched on any time of day or night, thus providing a kind of virtual energy storage. The process could thus serve as a useful dump for excess renewable electricity arising at times of high supply and low demand.

The electrolysis-GDA process could be applied not just to desalination reject brine but also to raw seawater. Nevertheless, we see advantages in using reject brine. Firstly, the infrastructure of power supply and brine discharge is already in place. Secondly, the higher concentration of salts in the brine gives higher conductivity which could assist the electrolysis process, as well as resulting in slightly lower electrical consumption according to the Nernst equation.

Future studies could include aspects of embodied energy in the desalination plants and electrolysis equipment, notwithstanding the methodological issues highlighted in existing life cycle assessments (LCA) of RO plants [48]. Another aspect to consider will be the environmental impacts of consumables such as anti-scaling and anti-fouling chemicals, and membrane replacements, as needed for the reverse osmosis and electrolysis processes.

\section{Conclusions}

This study has shown the potential to transform reverse osmosis (RO) desalination into a Negative Emissions Technology (NET) by the addition of electrolysis to treat the reject brine. Electrolysis with GDA splits the concentrated brine at a low voltage generating magnesium hydroxide that acts as a sink for $\mathrm{CO}_{2}$ in the ocean. Accompanying this process, high quality hydrochloric acid is also produced. Theoretical calculations show that:

1. The whole system could absorb 2.3 times the amount of $\mathrm{CO}_{2}$ emitted when powering the desalination plant by electricity generated from natural gas.

2. About $5 \mathrm{~kg}$ of net $\mathrm{CO}_{2}$ can be absorbed per net $\mathrm{m}^{3}$ of freshwater output from such a desalination plant, improving to $8.5 \mathrm{kgCO}_{2} / \mathrm{m}^{3}$ when powered from renewables.

3. Modification of existing plants for NET-desalination will incur an energy penalty of 1.8 $\mathrm{GJ} / \mathrm{tCO}_{2}$ and a water penalty of $13.7 \mathrm{~m}^{3} / \mathrm{tCO}_{2}$ removed. 
4. The energy penalty increases the overall SEC of the RO desalination plant considerably from 3 to $7.8 \mathrm{kWh} / \mathrm{m}^{3}$.

Though the energy and water penalties compare quite well against other NETs presented in the literature, the high SEC could make the technology seem unattractive to desalination plant operators unless there is an incentive to compensate for the increased economic cost. The technology is more likely to be introduced if subsidies are offered, perhaps linked to the achievement of INDCs, whereby the relatively modest energy penalty would make it economically attractive against other carbon abatement measures including injection of renewable energy to electricity grids.

NET-desalination can avoid excessive penalties of land or water. It could be more attractive for arid countries where water is unavailable to cultivate biomass at the scales needed for BECCS, and for island or city states that do not have much available land for cultivation (e.g. Dubai or Singapore). In this way, such countries could make a contribution to $\mathrm{CO}_{2}$ removal based on their existing or planned desalination infrastructure and this could be counted towards their INDC.

We foresee many challenges in implementing the electrolysis process reliably at scale, such as longevity of the systems, use of an economic and effective catalyst in the GDA, and maintaining uniform current densities in large systems as needed for today's desalination plants discharging approaching $1,000,000 \mathrm{~m}^{3}$ per day of brine. For this reason, we believe that a multi-disciplinary effort is important to research and scale up the approach from bench to pilot and then full scale, at the same time investigating broader effects such as ecological and economic impacts. Another related area for further research is to harvest the required energy input from salinity gradient power, or from wastewater treatment processes by means of microbial fuel cells, thus further improving the energy balance of the proposed NETdesalination $[49,50]$.

\section{References}

[1] UNFCCC, Report of the Conference of the Parties on its 21st session, part 2, 2015.

[2] J. Rogelj, M. Den Elzen, N. Höhne, T. Fransen, H. Fekete, H. Winkler, R. Schaeffer, F. Sha, K. Riahi, M. Meinshausen, Paris Agreement climate proposals need a boost to keep warming well below $2^{\circ} \mathrm{C}$, Nature, 534 (2016) 631-639.

[3] R.K. Pachauri, M.R. Allen, V. Barros, J. Broome, W. Cramer, R. Christ, J. Church, L. Clarke, Q. Dahe, P. Dasgupta, Climate change 2014: synthesis Report. Contribution of working groups I, II and III to the fifth assessment report of the intergovernmental panel on climate change, IPCC, 2014.

[4] S. Fuss, J.G. Canadell, G.P. Peters, M. Tavoni, R.M. Andrew, P. Ciais, R.B. Jackson, C.D. Jones, F. Kraxner, N. Nakicenovic, C. Le Quere, M.R. Raupach, A. Sharifi, P. Smith, Y. Yamagata, Betting on negative emissions, Nature Clim. Change, 4 (2014) 850-853.

[5] P. Smith, S.J. Davis, F. Creutzig, S. Fuss, J. Minx, B. Gabrielle, E. Kato, R.B. Jackson, A. Cowie, E. Kriegler, Biophysical and economic limits to negative $\mathrm{CO}_{2}$ emissions, Nature Climate Change, 6 (2016) 42-50.

[6] N. McGlashan, N. Shah, B. Caldecott, M. Workman, High-level techno-economic assessment of negative emissions technologies, Process Safety and Environmental Protection, 90 (2012) 501-510.

[7] D. McLaren, A comparative global assessment of potential negative emissions technologies, Process Safety and Environmental Protection, 90 (2012) 489-500.

[8] F. Zeman, Energy and Material Balance of $\mathrm{CO}_{2}$ Capture from Ambient Air, Environmental Science \& Technology, 41 (2007) 7558-7563. 
[9] K.Z. House, A.C. Baclig, M. Ranjan, E.A. van Nierop, J. Wilcox, H.J. Herzog, Economic and energetic analysis of capturing $\mathrm{CO}_{2}$ from ambient air, Proceedings of the National Academy of Sciences, 108 (2011) 20428-20433.

[10] K.S. Lackner, Capture of carbon dioxide from ambient air, The European Physical Journal Special Topics, 176 (2009) 93-106.

[11] R. Kiesgen de Richter, T. Ming, S. Caillol, Fighting global warming by photocatalytic reduction of CO2 using giant photocatalytic reactors, Renewable and Sustainable Energy Reviews, 19 (2013) 82106.

[12] C. Gough, P. Upham, Biomass energy with carbon capture and storage (BECCS or BioCCS), Greenhouse Gases: Science and Technology, 1 (2011) 324-334.

[13] National Research Council, Climate Intervention: Carbon Dioxide Removal and Reliable Sequestration, The National Academies Press, Washington, DC, 2015.

[14] R. Schuiling, P. de Boer, Rolling stones; fast weathering of olivine in shallow seas for costeffective $\mathrm{CO}_{2}$ capture and mitigation of global warming and ocean acidification, Earth System Dynamics Discussions, 2 (2011) 551-568.

[15] P. Renforth, B.G. Jenkins, T. Kruger, Engineering challenges of ocean liming, Energy, 60 (2013) 442-452.

[16] H.S. Kheshgi, Sequestering atmospheric carbon dioxide by increasing ocean alkalinity, Energy, 20 (1995) 915-922.

[17] K.Z. House, C.H. House, D.P. Schrag, M.J. Aziz, Electrochemical acceleration of chemical weathering as an energetically feasible approach to mitigating anthropogenic climate change, Environmental Science \& Technology, 41 (2007) 8464-8470.

[18] P. Renforth, G. Henderson, Assessing ocean alkalinity for carbon sequestration, Reviews of Geophysics, 55(2017) doi:10.1002/2016RG000533.

[19] N. Ghaffour, J. Bundschuh, H. Mahmoudi, M.F. Goosen, Renewable energy-driven desalination technologies: A comprehensive review on challenges and potential applications of integrated systems, Desalination, 356 (2015) 94-114.

[20] V.G. Gude, Desalination and sustainability-an appraisal and current perspective, Water research, 89 (2016) 87-106.

[21] IDA, IDA Yearbook - Water Desalination Report, 2016-2017.

[22] V. Ferrini, C. De Vito, S. Mignardi, Synthesis of nesquehonite by reaction of gaseous $\mathrm{CO}_{2}$ with $\mathrm{Mg}$ chloride solution: Its potential role in the sequestration of carbon dioxide, Journal of hazardous materials, 168 (2009) 832-837.

[23] F. Benyahia, Carbon dioxide mineralization using reject brine, US Patent 20,160,074,806, 2016.

[24] WOC, http://www.worldofchemicals.com/440/chemistry-articles/manufacturing-of-sodiumcarbonate-by-solvay-process.html, accessed 26 March 2018

[25] C.A. Summers, D.C. Dahlin, G.E. Rush, W.K. O'Connor, S.J. Gerdemann, Grinding methods to enhance the reactivity of olivine, Minerals and Metallurgical Processing, 22 (2005) 140-144.

[26] S.J. Gerdemann, D.C. Dahlin, W.K. O'Connor, L.R. Penner, Carbon dioxide sequestration by aqueous mineral carbonation of magnesium silicate minerals. Report No. DOE/ARC-2003-018., in, Albany Research Center (ARC), Albany, OR, 2003.

[27] USGS, https://minerals.usgs.gov/minerals/pubs/commodity/magnesium/mcs-2018-mgcom.pdf, accessed 26 March 2018.

[28] P.A. Davies, Solar thermal decomposition of desalination reject brine for carbon dioxide removal and neutralisation of ocean acidity, Environmental Science: Water Research \& Technology, 1 (2015) 131-137.

[29] C. Fernandez-Gonzalez, A. Dominguez-Ramos, R. Ibañez, A. Irabien, Electrodialysis with Bipolar Membranes for Valorization of Brines, Separation \& Purification Reviews, 45 (2016) 275-287.

[30] H. Xie, Y. Wang, W. Chu, Y. Ju, Mineralization of flue gas $\mathrm{CO}_{2}$ with coproduction of valuable magnesium carbonate by means of magnesium chloride, Chinese Science Bulletin, 59 (2014) 28822889. 
[31] W.M. Haynes, CRC handbook of chemistry and physics, CRC press, 2014.

[32] C. Fritzmann, J. Löwenberg, T. Wintgens, T. Melin, State-of-the-art of reverse osmosis desalination, Desalination, 216 (2007) 1-76.

[33] M.W. Shahzad, M. Burhan, L. Ang, K.C. Ng, Energy-water-environment nexus underpinning future desalination sustainability, Desalination, 413 (2017) 52-64.

[34] M. Elimelech, W.A. Phillip, The future of seawater desalination: energy, technology, and the environment, science, 333 (2011) 712-717.

[35] S. Allen, C. Pentland, A. Korre, Carbon Footprint of Electricity Generation. PostNote Update, No. 383, June 2011., The Parliamentary Office of Science and Technology, London, (2011) 4.

[36] IEA, How much carbon dioxide is produced per kilowatthour when generating electricity with fossil fuels? www.eia.gov/tools/faqs/faq.cfm?id=74\&t=11, accessed 25 March 2018.

[37] J. Wright, A. Colling, Open University Course Team, Seawater: Its Composition, Properties and Behavior, in, Pergamon-Elsevier, Oxford, 1995.

[38] F.J. Millero, R. Feistel, D.G. Wright, T.J. McDougall, The composition of Standard Seawater and the definition of the Reference-Composition Salinity Scale, Deep Sea Research Part I: Oceanographic Research Papers, 55 (2008) 50-72.

[39] B. Salgado, J.M. Ortega, J. Blazheska, J. Sanz, V. García-Molina, High-permeability FILMTEC ${ }^{\text {TM }}$ SEAMAXX ${ }^{\mathrm{TM}}$ reverse osmosis elements: a success story in the Canary Islands, Desalination and Water Treatment, 55 (2015) 3003-3011.

[40] T. Qiu, P.A. Davies, Comparison of Configurations for High-Recovery Inland Desalination Systems, Water, 4 (2012) 690.

[41] J. Peng, L. Lu, H. Yang, Review on life cycle assessment of energy payback and greenhouse gas emission of solar photovoltaic systems, Renewable and Sustainable Energy Reviews, 19 (2013) 255274.

[42] F. Asdrubali, G. Baldinelli, F. D’Alessandro, F. Scrucca, Life cycle assessment of electricity production from renewable energies: Review and results harmonization, Renewable and Sustainable Energy Reviews, 42 (2015) 1113-1122.

[43] P. Williamson, Scrutinize $\mathrm{CO} 2$ removal methods: the viability and environmental risks of removing carbon dioxide from the air must be assessed if we are to achieve the Paris goals, Nature, 530 (2016) 153-156.

[44] L. Harvey, Mitigating the atmospheric $\mathrm{CO} 2$ increase and ocean acidification by adding limestone powder to upwelling regions, Journal of Geophysical Research: Oceans, 113 (2008).

[45] R.C. Ropp, Encyclopedia of the alkaline earth compounds, Newnes, 2012.

[46] G.R. Rau, US Patent 20140234193A9, in.

[47] G.H. Rau, S.A. Carroll, W.L. Bourcier, M.J. Singleton, M.M. Smith, R.D. Aines, Direct electrolytic dissolution of silicate minerals for air $\mathrm{CO} 2$ mitigation and carbon-negative $\mathrm{H} 2$ production,

Proceedings of the National Academy of Sciences, 110 (2013) 10095-10100.

[48] J. Zhou, V.W.C. Chang, A.G. Fane, Life Cycle Assessment for desalination: A review on methodology feasibility and reliability, Water Research, 61 (2014) 210-223.

[49] A. Cipollina, G. Micale, Sustainable Energy from Salinity Gradients, Woodhead Publishing, 2016. [50] L. Lu, Z. Huang, G.H. Rau, Z.J. Ren, Microbial electrolytic carbon capture for carbon negative and energy positive wastewater treatment, Environmental science \& technology, 49 (2015) 8193-8201. 